Pobrane z czasopisma Studia Iuridica Lublinensia http://studiaiuridica.umes.pl Data: 26/04/2023 10:25:30

Articles Studia luridica Lublinensia vol. XXX, 4, 2021 DOI: 10.17951/sil.2021.30.4.301-313

Agnieszka Skóra

University of Warmia and Mazury in Olsztyn, Poland ORCID: 0000-0003-2169-5326

agnieszka.skora@uwm.edu.pl

Paweł Kardasz

Pomeranian Academy in Słupsk, Poland

ORCID: 0000-0002-4833-9375

pawel.kardasz@apsl.edu.pl

\title{
Legal Effects of Failures to Technical Devices and ICT Networks Which Are Used for Submitting Electronic Applications to Administrative Authorities and Legal Effects of Errors in Data Transmission of e-Submission: Comments Based on General Administrative Proceedings in Poland
}

Skutki prawne awarii środków technicznych lub sieci teleinformatycznej, za pomocą której wnoszone jest do organu podanie w postaci elektronicznej oraz skutki prawne błędu w transmisji danych e-podania. Uwagi na płaszczyźnie ogólnego postępowania administracyjnego

CORRESPONDENCE ADDRESS: Agnieszka Skóra, PhD, Dr. habil., Professor, University of Warmia and Mazury (Olsztyn), Faculty of Law and Administration, Institute of Administrative Proceedings and Court Administrative Proceedings Law, K. Obitza 2, 10-725 Olsztyn, Poland; Paweł Kardasz, PhD, Assistant Professor, Pomeranian Academy (Słupsk), Institute of Law and Administration, K. Arciszewskiego 22A, 76-200 Słupsk, Poland. 


\begin{abstract}
This paper aims at an analysis of legal effects of failures occurring to technical devices and ICT networks which are used for submitting electronic applications to administrative authorities within general administrative proceedings in form of e-submissions as well as legal effects of errors in data transmission in connection with the process of sending such submissions. Problems emerging in such situations make a very interesting yet not fully studied issue. So far no written analyses have been issued and the single cases that happen are resolved by administrative courts on an ad causam basis. Despite the fact that the administrative proceedings digitalization process has been going on for over 20 years, its importance has actually been confirmed now, during the COVID-19 pandemic, partially due to the necessity of meeting the sanitary measures, avoiding gatherings, limited or suspended operations of the public institutions on site which makes the electronic communication between the participants of administrative proceedings "attractive". For this reason, electronic administrative proceedings have become an attractive solution in this difficult and unpredictable period. The authors formulated here a hypothesis that malfunctions of technical devices or ICT networks used for submitting applications or motions may result even in failure to submit the said applications. In some cases, however, it is possible to eliminate such a negative effect by applying Article 58 of the Administrative Proceedings Code. On the other hand, an error in data transmission of an application consolidated in the electronic form depending on the nature of the error and the stage of the proceeding where such error has been noted may be - in the authors' opinion - as a rule, deemed a formal failing. Article 64 $\S 2$ of the Administrative Proceedings Code refers to the indicated cases.
\end{abstract}

Keywords: e-submission; error in data transmission; technical devices; ICT network; electronic communication

\title{
INTRODUCTION
}

The great practicability of submitting applications and motions to administrative authorities in the electronic form under the general administrative proceedings pattern, specified by the Act of 14 June 1960 - Administrative Proceedings Code, ${ }^{1}$ has specifically proved convenient during the COVID-19 pandemic. The epidemic, in a scope broader than usual, forced administrative authorities and proceedings participants to a mutual exchange of letters, submissions and other documents vital for the administrative decisions with the use of ICT communication devices. ${ }^{2}$ Despite undisputable advantages of electronic communication, such as remote dealing with administrative matters replacing the physical contact between the institution attendant and proceedings participants, has not ceased to be free from problems. For under provisions of general administrative proceedings such issues as failure of

${ }^{1}$ Consolidated text, Journal of Laws 2020, item 735, as amended, hereinafter: APC.

2 A. Skóra, P. Kardasz, K. Szelągowska, Ewolucja czy rewolucja doręczeń elektronicznych w czasach kryzysu? Przyczynek do dyskusji na temat komunikowania się organów administracji publicznej z jednostka na przyktadzie ustug hybrydowych, [in:] Cyfrowa czy analogowa? Funkcjonowanie administracji publicznej w stanie kryzysu, eds. A. Bochentyn, J.H. Szlachetko, Gdańsk 2021, p. 368. 
technical devices or ICT networks serving the electronic communication (hackers' attacks or software errors ${ }^{3}$ ) and failure of data transmission occurring in the process of e-submission forwarding to the administrative authorities (due to, say, the sender's server having automatically been marked as spam-producing by the addressee's server software, or the institution's e-mail box capacity overload or else, due to the connection getting cut because of too slow data transfer) have not yet been solved. ${ }^{4}$ In reference to this matter, the authors of this study deem it reasonable to recognise that currently the electronics-based communication, despite being an ideal manner in this virus-stricken situation, must not be treated as a "magic pill" enabling swift, effective, problem-free and informalised arrangement of all the administrative matters. In some situations, making use of the benefits of electronic communication by an administrative authority or participant of the proceedings may become the source of many problems arising from this form of information exchange. ${ }^{5}$

Having this in mind, a question is raised how to classify the occurrence of the above-mentioned technical difficulties in connection with devices or ICT networks which are meant to enable sending the e-submissions and in what way they will be removed: by parties (other participants of the proceedings) or by the administrative authorities themselves.

\section{E-SUBMISSION}

In order for an "electronic" submission to be named in this way under provisions of the general administrative proceedings, it must meet specific requirements. First of all, a motion must be submitted to an administrative authority in an electronic form $^{6}$ with the use of electronic communication devices meeting at the same time

${ }^{3}$ See, i.e., Kłopoty z ePUAP. Przerwa była dluższa niż planowano, 5.10.2019, https://tvn24.pl/ biznes/z-kraju/epuap-problemy-z-dostepem-do-systemu-przerwa-serwisowa-dluzsza-niz-planowano -ra974922-4508475 [access: 26.03.2021].

${ }^{4}$ B. Kwiatek, Dokument elektroniczny w ogólnym postępowaniu administracyjnym, Warszawa 2020, pp. 212-213.

${ }_{5}$ More broadly, see G. Sibiga, Stosowanie technik informatycznych w postepowaniu administracyjnym ogólnym, Warszawa 2019, pp. 23-24, 26-27.

6 In this study we use the phrase "electronic application", according to the wording of the Administrative Procedure Code as of October 5, 2021. This is a new terminological convention, introduced by the Act of 18 November on electronic service (Journal of Laws 2020, item 2320, as amended), hereinafter: ESA. In our opinion, "application in electronic form" is in fact the same as "application in the form of an electronic document". More on the matter of phrase "electronic document", see in G. Sibiga, op. cit., pp. 85-89; B. Kwiatek, op. cit., p. 119 ff.; A. Skóra, P. Kardasz, Electronic Document in the General Administrative Proceedings in Poland, [in:] Public and Private Law and the Challenges on New Technologies and Digital Markets, vol. 1: Regulatory Challenges, eds. E. Bani, B. Pachuca-Smulska, E. Rutkowska-Tomaszewska, Warszawa 2020, pp. 33-48. 
the formal requirements specified in the Administrative Proceedings Code and executive acts (Article $63 \S 1$ APC). Since 5 October 2021, there has been a rule in place that such an e-submission for administrative authorities must be sent to the address set up specifically for electronic deliveries under regulations specified in the Electronic Service Act. ${ }^{7}$ It must not, however, be forgotten that until 30 September 2029, the administrative authorities will still be obliged to respect the ePUAP service $^{8}$ and sending an e-submission with the use of the ePUAP system will cause legal effects equivalent to the services done under the Electronic Service Act. The territorial local government bodies are obliged to "switch" to electronic service as the basic method which will be compulsory starting with 1 January 2024, and on 1 January 2029, a hybrid service system will come into force.

Under Article 3 (4) of the Act of 17 February 2005 on the computerisation of entities performing public tasks ${ }^{9}$ in conjunction with Article 2 (5) of the Act of 18 July 2002 on services provided electronically, ${ }^{10}$ the term "electronic communication devices" is understood as technical solutions, including ICT devices and compatible software tools, enabling individual distant communication owing to data transmission between ICT systems, e-mail in particular. ${ }^{11}$ The mentioned definition indicates that the process of submitting applications to the administrative authorities in the electronic form covers three obligatory elements of ICT and technical infrastructure. Primarily it calls for using by both the entity and the party (or any other proceedings participant) an ICT device, such as computer, smartphone or tablet (hardware) along with the necessary software to make them going. ${ }^{12}$ This solution is created by two separate ICT systems on the part of the administrative authority and the party. The third necessary element enabling a proper delivery of submission

${ }^{7}$ Cf. G. Sibiga, op. cit., p. 89 ff.

${ }^{8}$ Electronic Platform of Public Administration Services (ePUAP) is, a Polish nationwide platform for communication of citizens with public administration in a uniform and standardized way. Service providers are public administration entities and courts and other public institutions. See Serwis ePUAP, www.gov.pl/web/cyfryzacja/serwis-epuap [access: 25.08.2021].

${ }^{9}$ Consolidated text, Journal of Laws 2020, item 346, as amended.

${ }^{10}$ Consolidated text, Journal of Laws 2020, item 344. According to Article 2 (1) ESA, the address for electronic service is the "electronic address referred to in Article 2 (1) of the Act of 18 July 2002 on the provision of electronic services [...], of the entity using the public electronic registered delivery service or public hybrid service, or a qualified electronic registered delivery service, that allows for the unambiguous identification of the sender or addressee of data transmitted as part of these services".

${ }^{11}$ G. Sibiga, op. cit., p. 144 ff.; A. Skóra, Selected aspects of electronic administration. Comments on means of communication between parties to general administrative proceedings and public authorities, "Zeszyty Naukowe Uniwersytetu Rzeszowskiego. Seria Prawnicza” 2019, no. 108, p. 179, 181.

${ }_{12}$ M. Świerczyński, [in:] Ustawa o świadczeniu ustug droga elektroniczną. Komentarz, ed. J. Gołaczyński, Warszawa 2009, p. 60. See also judgement of the Voivodeship Administrative Court in Warszawa of 16 April 2008, II SA/WA 1038/07, CBOSA; judgement of the Voivodeship Administrative Court in Gliwice of 4 October 2007, II SA/G1 291/07, CBOSA. 
in an electronic way is the ICT network (such as Internet) which with the use of a compatible end device (such as router) enables the data transmission between the two indicated ICT systems. The necessary iunctim of electronic communication devices is at the same time achieved by the very process of communicating based on the data transmission between ICT systems. ${ }^{13}$

It is worth mentioning that the feedback of the indicated technical devices is supposed to occur throughout the duration of the complete process of submitting the electronic motion to the administrative authorities. It is only their joint and flawless operation that guarantees the party an actual possibility of effective service of e-submissions to the administrative authorities (and vice versa - an effective service of replies). In this situation, a fault occurring to any of the three mentioned elements or an error in the data transmission is likely to cause serious or lesser irregularities in the course of delivering e-submissions. This may trigger negative procedure-based consequences not only for the submitting party but for other proceedings participants as well. ${ }^{14}$ Such situations are no rarity in the administrative practice, as mentioned before, and still, the Administrative Proceedings Code does not offer any remedy. They are not frequent mainly due to the reluctance of Polish society to perform electronic activities in the administrative proceedings. This reluctance - for various reasons - has been weakening very slowly. ${ }^{15}$ According to the report of the Central Statistical Office, 41,9\% of Polish society used e-government services in $2020 .{ }^{16}$ In the pandemic, it is especially surprising to find out that there were only $1.5 \%$ more users than there were in 2019 . The report also shows that $25.4 \%$ of the society $(0.8 \%$ more than in 2019) downloaded official e-forms and $33.5 \%$ of users sent back completed e-forms (2.1\% more than in 2019). ${ }^{17}$ In Poland, there are no records of statistics showing the number of initiated electronic administrative proceedings or what kind of matters they concerned. In the survey, the authors have analysed problems

${ }^{13}$ D. Szostek, Czynność prawna a środki komunikacji elektronicznej, Kraków 2004, pp. 35-36; B. Czerwińska, Wnoszenie i doręczanie pism za pomoca środków komunikacji elektronicznej w e-Urzędzie, [in:] Województwo - region - regionalizacja. 15 lat po reformie terytorialnej i administracyjnej, ed. J. Korczak, Wrocław 2013, pp. 170.

${ }_{14}$ A. Skóra, P. Kardasz, [in:] Kodeks postępowania administracyjnego. Komentarz, eds. M. Karpiuk, P. Krzykowski, A. Skóra, vol. 2, LEX/el. 2020, comment to Article 64.

${ }_{15}$ In our opinion, the reason for this state of matters are the frequent failures of the ePUAP system, poor computerisation of the administrative authorities (specifically the territorial local government bodies), the obligation of producing on many occasions paper documents to the administrative authorities and the adhesion to the traditional settlement of matters with the use of paper documents. In practical terms, it undermines the participants' trust in e-communication with administrative authorities.

${ }^{16}$ Główny Urząd Statystyczny / Urząd Statystyczny w Szczecinie, Społeczeństwo informacyjne w Polsce w 2020 r., Warszawa-Szczecin 2020, p. 163.

17 Ibidem. 
solved by administrative courts (in 2011-2020 about 30 judgements were given, quoted in the footnotes) and made use of communications on equipment failures and transmission errors found in the legal press.

\section{LEGAL EFFECTS OF TECHNICAL DEVICES AND ICT NETWORK FAILURES AS WELL AS ERRORS IN ELECTRONIC DATA TRANSMISSION}

Technical devices and ICT network failures occur when technical damage arises to the devices such as computers, tablets, smartphones and/or to ICT network (e.g., Internet), their usage is impossible or when they can be used but it is done in an improper way. ${ }^{18}$ Failure to technical devices or ICT network may result in making it impossible to submit any documents in electronic form. However, sometimes despite a failure, an e-submission may be sent to an administrative authority but in an incomplete or deformed way (such as damaged form's file). This is called "error in electronic data transmission". 19

"Electronic data" is understood as converted (or created) details in the form fit for the application in the IT system and saved on a data storage device to be processed by IT programs. ${ }^{20}$ As a rule, electronic data is saved in a double (binary) system. ${ }^{21}$ In order to be able to create, change and read it, a digital data storage device is necessary which will transfer and decode such data. It is at the data transfer stage and its decoding process that the above-mentioned failures usually occur which result in disorders of the electronic submissions delivery. ${ }^{22}$

As mentioned above, failure to technical devices or IT systems may cause in the first instance inability for e-submission to be delivered to the administrative authority at all. In such a case, as a rule, no effective proceedings are instituted. This is due to the fact that not any of the basic premises for initiating proceedings occur in such a situation, i.e. no motion by a party will be filed (in the administrative authority of first or second instance, nor appeals in extraordinary proceedings). Moreover, since the regulations provide a legally substantive date for the submission and, due to the failure, the party did not meet it, there is no reason for its resumption. However, if the initiation of the proceedings is not limited by a specific substantial term, the party

18 P. Kardasz, Podanie $w$ formie dokumentu elektronicznego $w$ ogólnym postępowaniu administracyjnym, Olsztyn 2020 (unpublished doctoral dissertation), p. 360.

19 Ibidem, p. 362.

${ }^{20}$ See Electronic Data definition, www.lawinsider.com/dictionary/electronic-data [access: 26.03.2021].

${ }^{21}$ Cf. G. Coldwind, Zrozumieć programowanie, Warszawa 2015, p. 108 ff.

${ }^{22}$ P. Kardasz, op. cit., p. 362; A. Skóra, P. Kardasz, [in:] Kodeks postępowania administracyjnego..., comment to Article 64 . 
is free to submit the document anew and have their administrative matter settled. Failure to technical devices or ICT systems may also have caused effects equivalent to non-execution of a specific action within the proceedings. Such an effect will be observed in the case of e-submissions delivered by a party or other participants of the proceedings already in the course of the initiated proceedings (such as an application for the resumption of suspended proceedings, etc.). Under Articles 41 and 42 ESA, once the e-application has entered the service address of an administrative authority, the participant is supposed to automatically be given in return the so-called proof confirming the submission of the application. Should he not get such proof, it is his responsibility then to prove the fact of having e-submitted a document.

In the first of the mentioned cases, when the participant has not received confirmation of submitting the application, regulations concerning inaction of an administrative authority may not be applied as e-submission has not effectively been delivered.

In the other of the mentioned cases where the e-submission was a subsequent submission in the same matter (e.g., a submission for the resumption of suspended proceedings), and the participant has not received confirmation of submitting the application, the application of Article $58 \mathrm{APC}^{23}$ can be considered. Following Article 58 § 1 APC, should the date not have been met, the date must be resumed on request of the concerned person on condition they make it plausible that the failure to comply with the time limit occurred for no default of theirs. The request for the resumption of the proceedings must be filed within seven days of the day the reasons for non-complying have ceased. Along with the request, the action must be completed for which the date limit has been set (Article $58 \S 2$ APC). It is practical to indicate that the mentioned legal institution may be made use of by the party (or another participant of the proceedings) exclusively in the case of the occurrence of independent, exceptional and unforeseen circumstances (obstacles) during the process of e-submission delivery, which are impossible to remove even despite the application of the respective utmost effort, which includes a hacker's attack, system virus, computer crash ${ }^{24}$ server-room or the so-called data centre fire, ${ }^{25}$ etc. Yet, the discussed regulation will not be applied in the case of the party's (or other participant's) non-complying with the time limit, even as slight negligence. ${ }^{26}$ What is more, according to judicial decisions, the occurrence of failures of technical

${ }^{23}$ P. Kardasz, op. cit., p. 364.

${ }^{24}$ Cf., i.e., judgement of the Supreme Administrative Court of 13 December 2019, II OSK 278/18, LEX no. 2754149; judgement of the Supreme Administrative Court of 9 October 2019, I OSK 401/19, CBOSA.

${ }^{25}$ See B. Sieja, Pożar serwerowni OVH. Część stron może nie działać, wiele firm utraciło dane, 10.03.2021, www.komputerswiat.pl/aktualnosci/internet/pozar-serwerowni-ovh-czesc-stron-mozenie-dzialac-wiele-firm-utracilo-dane/sq7rvm8 [access: 26.03.2021].

26 See, i.e., judgement of the Supreme Administrative Court of 30 April 2020, I OSK 11/19, LEX no. 2974096; judgement of the Supreme Administrative Court of 14 May 1998, IV SA 1153/96, 
devices or ICT networks in the course of submitting e-documents in the situation when a party (other participant of the proceedings) had other possibilities of delivering the submission (such as selected postal operator), as a rule does not make grounds for applying here Article $58 \mathrm{APC}$. As a result, for the purpose of resuming the date for the delivery of the submission, the party (or other participant of the proceedings) not only must make the fact of the occurrence of a given failure to the technical device serving as a means for such delivery plausible (e.g., a hacker's attack, etc.) but also the probability of the fact of not receiving the automatic confirmation of submitting of the e-application under Articles 41 and 42 ESA and the impossibility of submitting a given application with the use of one of other methods of service specified in Article $63 \S 1$ in conjunction with Article 14 APC must be proven beyond doubt. ${ }^{27}$ It must be here emphasised that in the Polish case law, difficulties with the operation of an ICT system for e-submissions or its retarded action faced by the party (or other participant of the proceedings) may not make grounds for the resumption of the date limit for the submission by the administrative authority in the event there exist objective opportunities for the delivery of such submissions with the use of the system on the same day or later. ${ }^{28}$ An analysis of the judgements of Polish administrative courts allows us to conclude that the legislator silently accepts the fact that the very initiation of electronic communication with the administrative authority gives rise to an allegation that the party (or other participant of the proceedings) has had sufficient knowledge and technical skills necessary for carrying on the proceedings within which the actions are executed and digitally stored.

A problem worth a separate analysis involves the judgement of legal effects of technical devices or ICT systems' failures which trigger errors in the (electronic) data transmission within the e-submission process. As mentioned before, in such a case the submissions are actually delivered to the authorities, however, in an incomplete form (lacking the e-signature or a request) or deformed (e.g., "cut" e-form). ${ }^{29}$ These cases seem to present absence of shortages of form in reference to such a submission which - generally - are possible to be removed. The indicated shortages are the shortage of form nature because they do not meet the formal requirements regarding their form and contents, provided expressis verbis by the

CBOSA; judgement of the Voivodeship Administrative Court in Warszawa of 19 December 2019, VII SA/Wa 1903/19, LEX no. 2777620.

27 Cf., i.e., decision of the Supreme Administrative Court of 14 June 2012, II OZ 495/12, LEX no. 1332696; judgement of the Voivodeship Administrative Court in Warszawa of 21 April 2017, V SA/Wa 1379/16, CBOSA.

${ }_{28}$ See, i.e., judgement of the Supreme Administrative Court of 24 April 2018, II GSK 1947/16, CBOSA; judgement of the Voivodeship Administrative Court in Warszawa of 17 March 2010., V SA/ Wa 1876/09, LEX no. 606136.

${ }^{29}$ A. Skóra, P. Kardasz, [in:] Kodeks postępowania administracyjnego ..., comment to Article 64. 
respective law. In our opinion, in the situations where electronic data transmission suffers an error, thus occurring defects to the content and/or form of an e-submission may be removed, principally speaking, using a respective provision of Article $64 \S 2$ APC,${ }^{30}$ unless provisions of procedural law directly provide otherwise. It is worth remembering that for the purpose of determining both the fact of the occurrence of a shortage to the form of the submission and its scope, by applying formal verification the authority may make use of the metadata attached to the given submission (e-document). ${ }^{31}$ The recommended procedures to be followed in such cases are advisable due to the fact that an e-submission is a modern equivalent of hard copy application brought to the desk of a clerk, thus its shortages of form should be treated as shortages of form of a paper document unless respective provisions of law expressly state otherwise.

The above arrangements allow for a statement that in the event of the occurrence of an error to the data transmission while submitting an e-submission which results in an incomplete or deformed delivery, the given authority is supposed to summon the party (or other participant of the proceedings) - through electronic means of communication - to remove the errors from such e-submission within stated time limit. ${ }^{32}$ According to Article $64 \S 2$ APC, such a time limit must not be shorter than seven days and the summons must contain instructions explaining the failure to meet the deadline results in non-consideration of the submission by the administrative authority. The manner of removing the shortages of form depends on the very nature of such a shortage and the stage of the proceedings within which the e-submission was delivered. ${ }^{33}$ Should the shortage of form in e-submission be convalidated, a legal fiction will be accepted that such an e-submission has not suffered this kind of shortage of form since the onset of its transmission. This means that the date of the commencement of the proceedings in the case of the requirement of the matter settlement contains shortages of form is the day the e-submission takes place rather than the day of completion of the shortages. Simultaneously, should the participant not remove errors within the time set by the administrative authority, the same authority

${ }^{30}$ According to Article $64 \S 2 \mathrm{APC}$, "if the application does not fulfil the requirements of law, the applicant shall be summoned to correct the defects within not less than 7 days, with a notice advising that failure to comply will result in the application not being examined". See also P. Kardasz, op. cit., p. 365.

31 J. Adamus, Metadane w archiwizacji dokumentów elektronicznych, "Zagadnienia Informacji Naukowej” 2009, no. 2, pp. 13-28; K. Schmidt, Metadane w cyklu życia dokumentu elektronicznego, "Elektroniczna Administracja" 2008, no. 3, pp. 50-58.

${ }^{32}$ See, i.e., judgement of the Voivodeship Administrative Court in Poznań of 26 June 2014, II SA/Po 519/14, CBOSA; decision of the Supreme Administrative Court of 4 June 2014, II GSK 1197/14, CBOSA; judgement of the Voivodeship Administrative Court in Poznań of 10 December 2014, II SA/Po 616/14, CBOSA; judgement of the Supreme Administrative Court of 23 February 2018, II OSK 1901/17, CBOSA.

${ }^{33}$ More broadly, see P. Kardasz, op. cit., p. $111 \mathrm{ff}$. 
is free to leave such an electronic submission without consideration, which is directly provided in Article $64 \S 2$ APC. Leaving errors or gaps without having considered them means that the administrative authority concerned "shall not set the wheels in motion" and such an e-submission will not be substantively considered. ${ }^{34}$ It is only the administrative authority that is exclusively eligible for a precise notification of the shortages in the summons of the shortages to the formal e-submission. It has been commonly accepted in literature and in court jurisdiction that making an administrative authority obliged to request the participants of proceedings to rectify and the documents and instructing them on the effects of failure to do so, is connected with the principle of protecting individuals against negative effects of the ignorance of law set by Administrative Proceedings Code (Article 9). Consistently with this general principle used in the proceedings, gaps in the documents may not cause immediately its becoming void and result in its not being processed. ${ }^{35}$

\section{CONCLUSIONS}

The presented considerations allow for the following conclusions. Firstly, there is no doubt that electronic communication of the participants of proceedings - despite all undisputable conveniences - might sometimes pose problems. Therefore it must not be regarded as an always fast and formalism-free method of arranging administration matters. Every participant of the proceedings should be aware that submitting an e-application may be "disturbed" due to some technical failure and the ICT network used for electronic communication. There may also occur errors in the data transmission while sending e-submissions to authorities. Defects to technical devices and ICT networks used for transmitting e-submissions may result even in a complete failure to submit such e-documents. In some of the above-mentioned cases, it is possible to eliminate those negative effects by a proper application of Article 58 APC. On the other hand, errors in data transmission of the submission stored in an electronic way may, as a rule, be regarded as shortages of form of the document depending on the error type and the stage of the proceeding. Article 64 $\S 2$ APC shall be used for the completion of such shortages.

Another conclusion puts forward a statement that submitting e-papers by participants of the proceedings brings a legal presumption that in technical terms, they have been well prepared for initiating and carrying on with the proceedings (i.e., are furnished with proper IT equipment, the right software and access to the network) and possess the required skills for the service of the devices. A propos the well-known

34 A. Skóra, P. Kardasz, [in:] Kodeks postępowania administracyjnego ..., comment to Article 64.

35 Judgement of the Supreme Administrative Court of 23 February 2018, II OSK 1901/17, CBOSA. 
legal maxim ignorantia iuris nocet, one may conclude that the fact of e-submission causes for the participant a new, unknown until that moment, presumption: "ignorance of the technics is no excuse" (ignorantia technicae artis technicae nocet). If a participant initiates the electronic proceedings, he must be aware of the challenges and technical problems resulting from this type of communication and he must not keep the administrative authority responsible for the effects of such risks. In particular, he should not wait until the so-called last moment for submitting the documents, specifically when the regulations provide a strict time limit. Having sent the e-submission, the participant reflects he is not sufficiently prepared in technical terms for continuing the procedure electronically, he may completely abandon the electronic communication which makes the administrative authority continue the process in the paper form. Such a conclusion is provided by Article 39 APC.

Thirdly, it must be mentioned that the results of the discussed failures and errors occurring during e-submission data transmission encumber - depending on the situation - the participants of the proceedings or administrative authority. The results burden the participants specifically in the situation they do not have the electronic certification of the e-application having been sent on hand and have not exercised due diligence while processing it. However, if the errors have occurred solely on the part of the administrative authority (such as ePUAP failure or resulting transmission errors) while the participants have exercised due diligence when processing the documents and have received the submission certification (or can produce a screenshot of the communication of the occurred error), the consequences burden the administrative authority. At this point, the e-application shall be deemed to have successfully been sent to the ePUAP system of the administrative authority. Yet, in the situation when the substantive law deadline has elapsed, the liability for damages (vindicated in civil law proceedings) - as a rule - should be carried by the administrative authority.

\section{REFERENCES}

\section{Literature}

Adamus J., Metadane $w$ archiwizacji dokumentów elektronicznych, "Zagadnienia Informacji Naukowej" 2009, no. 2.

Coldwind G., Zrozumieć programowanie, Warszawa 2015.

Czerwińska B., Wnoszenie i doręczanie pism za pomoca środków komunikacji elektronicznej w e-Urzędzie, [in:] Województwo - region - regionalizacja. 15 lat po reformie terytorialnej $i$ administracyjnej, ed. J. Korczak, Wrocław 2013.

Główny Urząd Statystyczny / Urząd Statystyczny w Szczecinie, Społeczeństwo informacyjne w Polsce w 2020 r., Warszawa-Szczecin 2020.

Kardasz P., Podanie w formie dokumentu elektronicznego w ogólnym postępowaniu administracyjnym, Olsztyn 2020 (unpublished doctoral dissertation).

Kwiatek B., Dokument elektroniczny w ogólnym postępowaniu administracyjnym, Warszawa 2020. 
Schmidt K., Metadane w cyklu życia dokumentu elektronicznego, "Elektroniczna Administracja" 2008, no. 3 .

Sibiga G., Stosowanie technik informatycznych w postępowaniu administracyjnym ogólnym, Warszawa 2019.

Skóra A., Selected aspects of electronic administration. Comments on means of communication between parties to general administrative proceedings and public authorities, "Zeszyty Naukowe Uniwersytetu Rzeszowskiego. Seria Prawnicza" 2019, no. 108,

DOI: https://doi.org/10.15584/znurprawo.2019.27.15.

Skóra A., Kardasz P., [in:] Kodeks postępowania administracyjnego. Komentarz, eds. M. Karpiuk, P. Krzykowski, A. Skóra, vol. 2, LEX/el. 2020.

Skóra A., Kardasz P., Electronic Document in the General Administrative Proceedings in Poland, [in:] Public and Private Law and the Challenges on New Technologies and Digital Markets, vol. 1: Regulatory Challenges, eds. E. Bani, B. Pachuca-Smulska, E. Rutkowska-Tomaszewska, Warszawa 2020.

Skóra A., Kardasz P., Szelągowska K., Ewolucja czy rewolucja doręczeń elektronicznych w czasach kryzysu? Przyczynek do dyskusji na temat komunikowania się organów administracji publicznej z jednostka na przyktadzie ustug hybrydowych, [in:] Cyfrowa czy analogowa? Funkcjonowanie administracji publicznej w stanie kryzysu, eds. A. Bochentyn, J.H. Szlachetko, Gdańsk 2021.

Szostek D., Czynność prawna a środki komunikacji elektronicznej, Kraków 2004.

Świerczyński M., [in:] Ustawa o świadczeniu usług droga elektroniczną. Komentarz, ed. J. Gołaczyński, Warszawa 2009.

\section{Online sources}

Electronic Data definition, www.lawinsider.com/dictionary/electronic-data [access: 26.03.2021].

Kłopoty z ePUAP. Przerwa była dluższa niż planowano, 5.10.2019, https://tvn24.pl/biznes/z-kraju/epuap-problemy-z-dostepem-do-systemu-przerwa-serwisowa-dluzsza-niz-planowano -ra974922-4508475 [access: 26.03.2021].

Serwis ePUAP, www.gov.pl/web/cyfryzacja/serwis-epuap [access: 25.08.2021].

Sieja B., Pożar serwerowni OVH. Część stron może nie działać, wiele firm utraciło dane, 10.03.2021, www.komputerswiat.pl/aktualnosci/internet/pozar-serwerowni-ovh-czesc-stron-moze-nie-dzialac-wiele-firm-utracilo-dane/sq7rvm8 [access: 26.03.2021].

\section{Legal acts}

Act of 14 June 1960 - Administrative Proceedings Code (consolidated text, Journal of Laws 2020, item 735 , as amended).

Act of 18 July 2002 on the provision of electronic services (consolidated text, Journal of Laws 2020, item 344).

Act of 17 February 2005 on the computerisation of entities performing public tasks (consolidated text, Journal of Laws 2020, item 346, as amended).

Act of 18 November 2020 on electronic service (Journal of Laws 2020, item 2320, as amended)

\section{Case law}

Decision of the Supreme Administrative Court of 14 June 2012, II OZ 495/12, LEX no. 1332696.

Decision of the Supreme Administrative Court of 4 June 2014, II GSK 1197/14, CBOSA.

Judgement of the Supreme Administrative Court of 14 May 1998, IV SA 1153/96, CBOSA.

Judgement of the Supreme Administrative Court of 23 February 2018, II OSK 1901/17, CBOSA. 
Judgement of the Supreme Administrative Court of 24 April 2018, II GSK 1947/16, CBOSA. Judgement of the Supreme Administrative Court of 9 October 2019, I OSK 401/19, CBOSA. Judgement of the Supreme Administrative Court of 13 December 2019, II OSK 278/18, LEX no. 2754149.

Judgement of the Supreme Administrative Court of 30 April 2020, I OSK 11/19, LEX no. 2974096. Judgement of the Voivodeship Administrative Court in Gliwice of 4 October 2007, II SA/G1 291/07, CBOSA.

Judgement of the Voivodeship Administrative Court in Warszawa of 16 April 2008, II SA/WA 1038/07, CBOSA.

Judgement of the Voivodeship Administrative Court in Warszawa of 17 March 2010, V SA/Wa 1876/09, LEX no. 606136.

Judgement of the Voivodeship Administrative Court in Poznań of 26 June 2014, II SA/Po 519/14, CBOSA.

Judgement of the Voivodeship Administrative Court in Poznań of 10 December 2014, II SA/Po $616 / 14$, CBOSA.

Judgement of the Voivodeship Administrative Court in Warszawa of 21 April 2017, V SA/Wa 1379/16, CBOSA.

Judgement of the Voivodeship Administrative Court in Warszawa of 19 December 2019, VII SA/Wa 1903/19, LEX no. 2777620.

\section{ABSTRAKT}

Celem artykułu jest analiza skutków prawnych awarii środków technicznych oraz sieci teleinformatycznej, za pomocą której w ogólnym postępowaniu administracyjnym wnoszone są do organu administracji publicznej podania w postaci elektronicznej oraz skutków prawnych błędu w transmisji danych związanych z procesem przesyłania takich podań. Problemy wyłaniające się na tym tle stanowią bardzo interesującą, a jednocześnie niezbadaną problematykę. Nie doczekała się ona dotąd analizy w piśmiennictwie, a poszczególne przypadki, wyłaniające się na jej tle, rozstrzygane są w orzecznictwie sądowym ad causam. Mimo że informatyzacja postępowania administracyjnego dokonuje się stopniowo od ponad 20 lat, jej znaczenie praktyczne stało się szczególnie istotne w czasie pandemii COVID-19, m.in. ze względu na konieczność zachowania reżimu sanitarnego, unikania skupisk ludzkich, ograniczenia lub nawet wyłączenia pracy urzędów, co czyni ,atrakcyjnym” komunikację elektroniczną między uczestnikami postępowania administracyjnego. Tym samym elektroniczne postępowanie administracyjne stało się interesującym rozwiązaniem proceduralnym w tym trudnym i nieprzewidywalnym okresie. Autorzy postawili tezę, że awaria środków technicznych lub sieci teleinformatycznej, za pomocą której wnoszone są podania w postaci elektronicznej, może skutkować nawet niewniesieniem podania. W niektórych przypadkach możliwa jest jednak eliminacja tego negatywnego skutku poprzez odpowiednie zastosowanie art. 58 k.p.a. Natomiast błąd w transmisji danych podania utrwalonego w postaci elektronicznej w zależności od rodzaju błędu i etapu postępowania, w których błąd ten odnotowano, zdaniem autorów można co do zasady zaliczyć do braków formalnych takiego podania. We wskazanych przypadkach odpowiednie zastosowanie znajdzie przepis art. $64 \S 2$ k.p.a.

Słowa kluczowe: e-podanie; błąd w transmisji danych; środki techniczne; sieć teleinformatyczna; komunikacja elektroniczna 